\title{
A BIRDER LOOKS AT FLOWERS
}

\section{ANTHONY J. ERSKINE, P.O. Box 1327, Sackville, NB EOA 3C0}

The Editor knows that if you "scratch a naturalist, you'll find a birder inside," and has offered some ideas why that is so. A major reason is that birds move, whether to pick sunflower seeds out of people's hands or to chase squirrels around the back yard (see Blue Jay 54(4):ii). Flowers are attractive to most people, but they move only when the wind blows or people pick them. You can describe what and where they are, and how many, but not what they do. Some birders however, including the Editor and I, see them too.

In my first summer in the prairie provinces (studying Buffleheads in Alberta, 1964) ${ }^{2}$ I didn't have a plant book along and I took few notes, though my slides included a well-

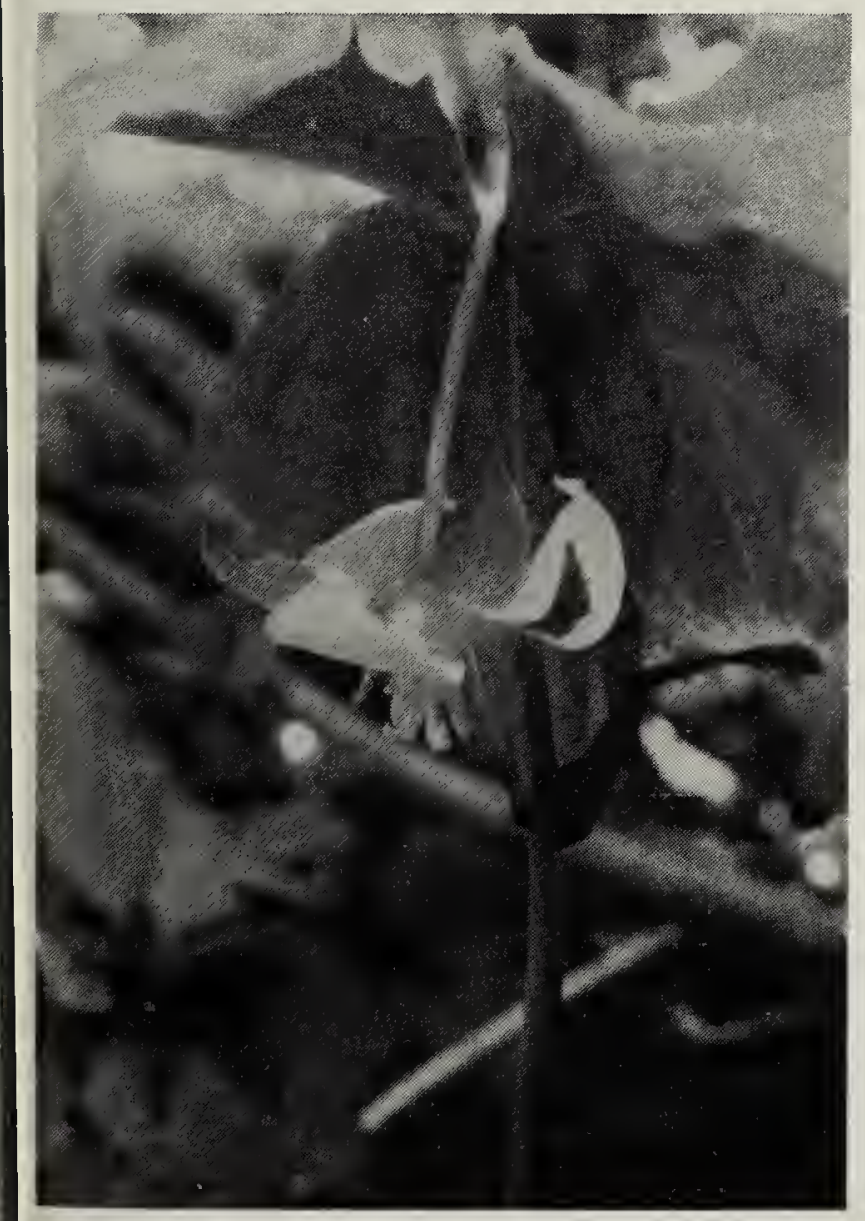

Trillium cernuum (Nodding Trillium)

Wayne C. Harris defined "trail of cottongrass" (Eriophorum vaginatum var. spissum) marking plant regeneration along a bulldozed seismic line (for oil exploration). On returning to Manitoba for bird census work in 1972, I took along a copy of Scoggan's Flora of Manitoba, ${ }^{6}$ then the authoritative plant list there. My field work then was around Mafeking, Manitoba on the eastern edge of the Porcupine Provincial Forest with measured plots in various habitats on which, besides birds, flowering plants that were new or interesting to me were noted. It wasn't a systematic plant study, ${ }^{4}$ but it produced some apparent novelties.

From the first week of surveys, it was obvious that hardly anyone had collected plant specimens in that part of Manitoba, which for Scoggan meant that the species wasn't known there. Nodding Trillium (Trillium cernuum) was frequent in the poplar plot, but Scoggan knew of no records/specimens north of Riding Mountain. More notably, Purple Clematis (Clematis verticillaris), which I knew well from Ontario, was listed only as hypothetical, with no specimens known from Manitoba, although the species had been reported. After reading that account, I returned to the balsam fir stand to get a photo of the one l'd found, but I couldn't relocate it (even with notes). When I was next in that region, 20 years later (1992), I found Purple Clematis in several places, but by then others also had found and reported it locally. Slender Beardtongue, Penstemon gracilis, was another flower noted in 1972 that hadn't 
been collected so far north when Scoggan's Flora was published.

The small balsam fir area northeast of Mafeking was also notable for orchids, of which no specimens were collected (only memories). By the time the surveys were completed in early July, nine species and one additional variety of orchids were noted on that 16-ha plot. In order of their flowering, with numbers of plants and first date seen there, were:

- Fairy-slipper Calypso bulbosa (3, 14 May);

- Yellow Lady-slipper Cypripedium calceolus, both typical and small [var. parviflorum] (3, 9 June; and 21, 9 June);

- Green Coralroot Corallorhiza trifida (4, 9 June);

- Spotted Coralroot Corallorhiza maculata (28, 11 June);

- Round-leaved Orchis Orchis rotundifolia (33, 18 June);

- Round-leaved Fringed-orchid Habenaria orbiculata (1, 18 June);

- Showy Lady-slipper Cypripedium reginae (1, 30 June);

- Northern Green Fringed-orchid Habenaria hyperborea $(10,4$ July);

- Blunt-leaved Fringed-orchid Habenaria obtusata (1, 4 July).

Possibly some of the later-blooming orchids also occur there, but bird song was ceasing and I left the area 9 July.

The balsam fir plot was a good site, as no other orchid species turned up on the other plots that year, and four of those listed above were found only on the balsam fir plot. Evidently that was the richest habitat as to orchid diversity, with more species even than in the Turtleford area Muriel Carlson laboured to protect. ${ }^{1}$ I have only once seen the Showy Lady-slipper since then, and another showy flower there that I never met again was the Fringed Milkwort (Polygala paucifolia).

The variety of orchids there was impressive, but some orchid species occurred in much larger numbers on bird census plots worked in other years. Orchids aren't always as rare as they often are made out to be, although they easily can become rare if people pick them in bunches. Near Dore Lake, Saskatchewan, in 1973, my notes included over 600 plants of Spotted Coralroot on a mature birch/poplar plot before I gave up counting them, and there were over 120 plants of Northern Green Fringed-orchid in a black spruce stand there. On 4 June 1974, in another black spruce area on lower slopes of Steamboat Mountain, BC (mile 346, Alaska Hwy, elev. 650 m), I was delighted by over 135 flowering plants of Fairy-slipper, including 73 plants so massed as to fill a $35 \mathrm{~mm}$ camera slide.

Those numbers were counts of plants seen along the marked lines of the plot grid; extrapolation to the full area of those plots suggested much larger numbers. For example, with lady's-slippers and Fairy-slipper assume that I detected half the blooms in a strip $5 \mathrm{~m}$ wide on either side of each line. With Green Fringed-orchids and coralroots, it would be optimistic to assume that I saw half the blooms, even in a strip only half that wide. As grid lines on those plots were $50 \mathrm{~m}$ apart, extrapolation using those detection rates indicated over 12,000 Spotted Coralroot plants and over 2,400 Green Fringed-orchids on those 


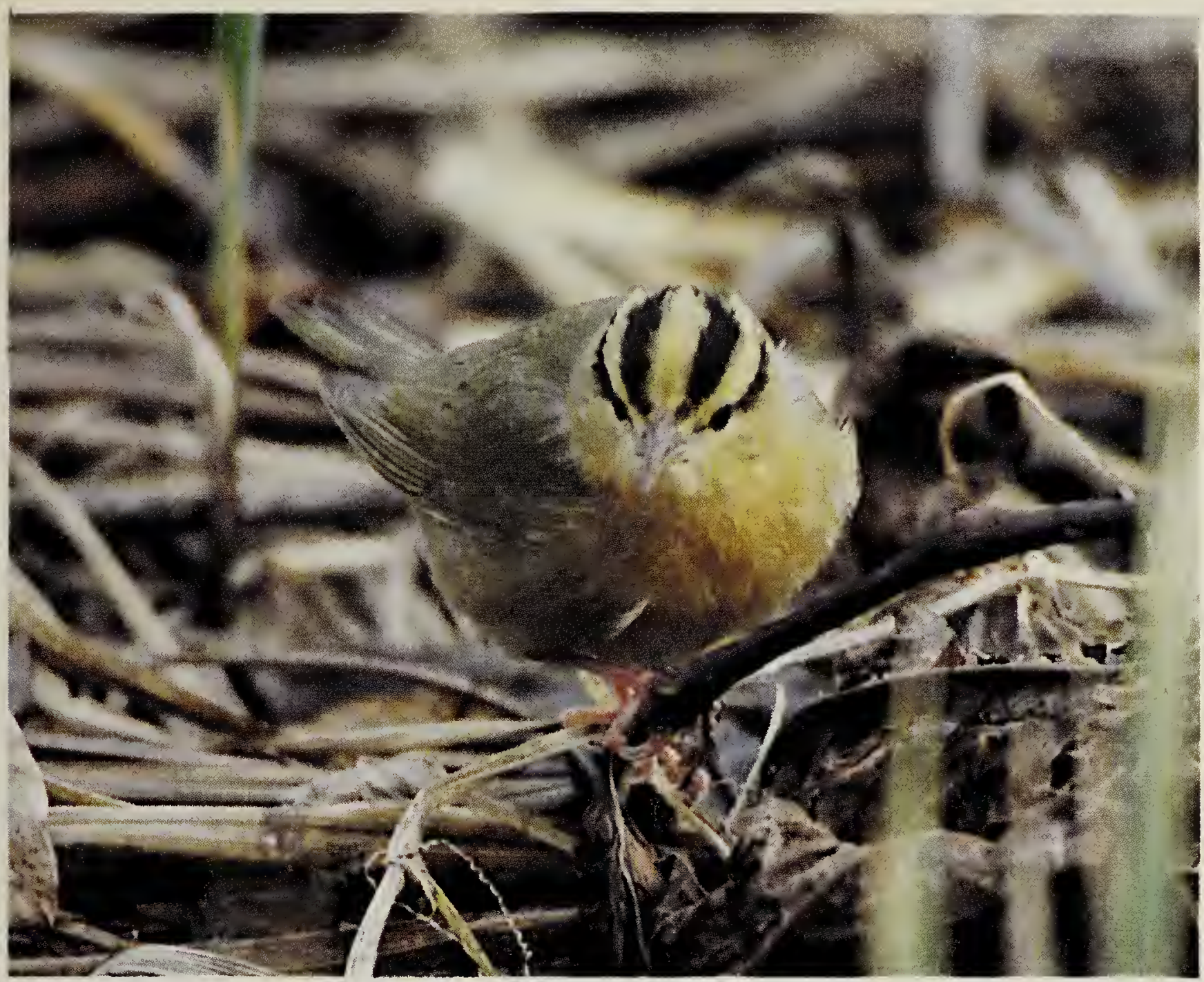

Worm-eating Warbler, a new Manitoba record

Dennis Fast

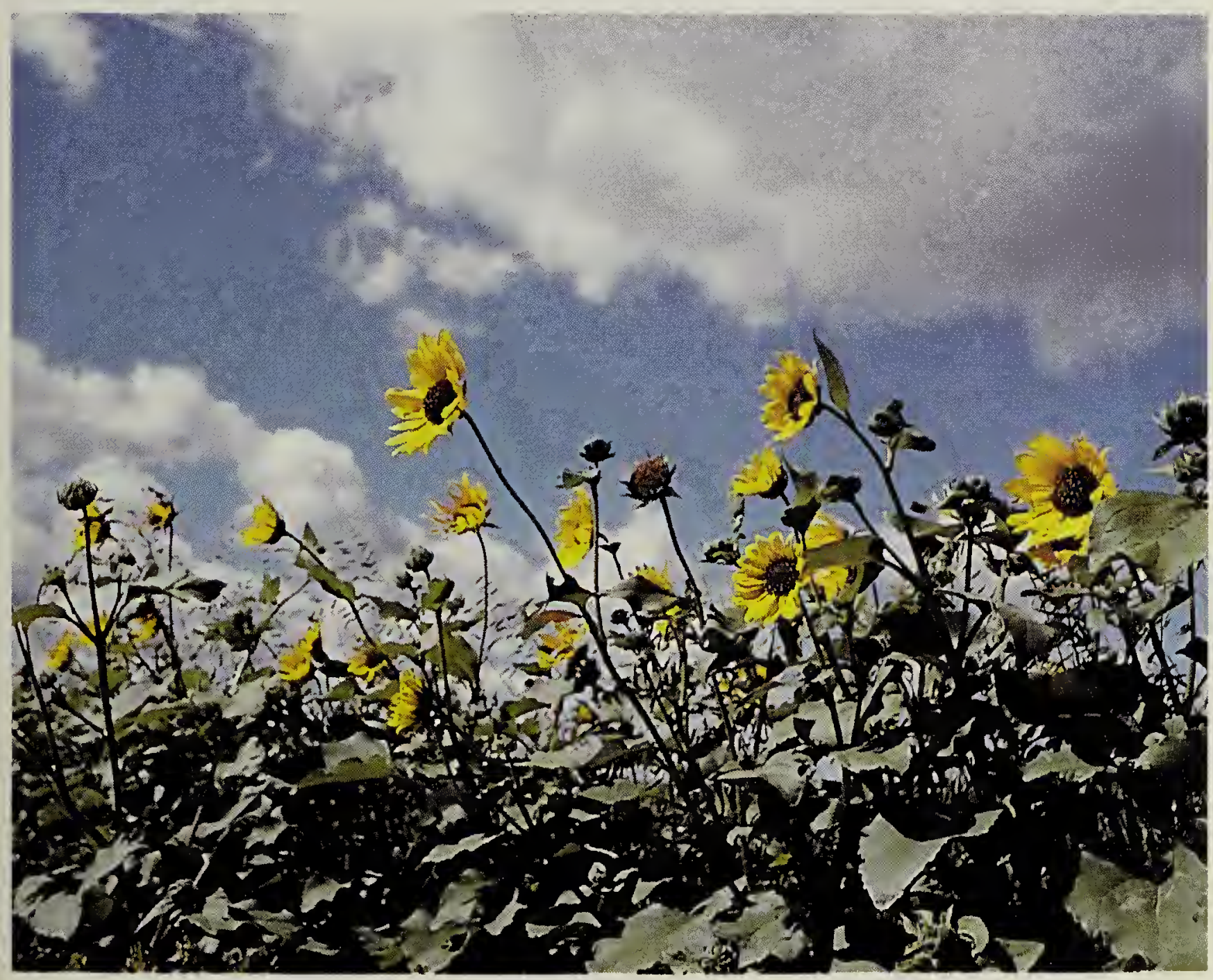

Dryland Sunflower

Clare Hume 


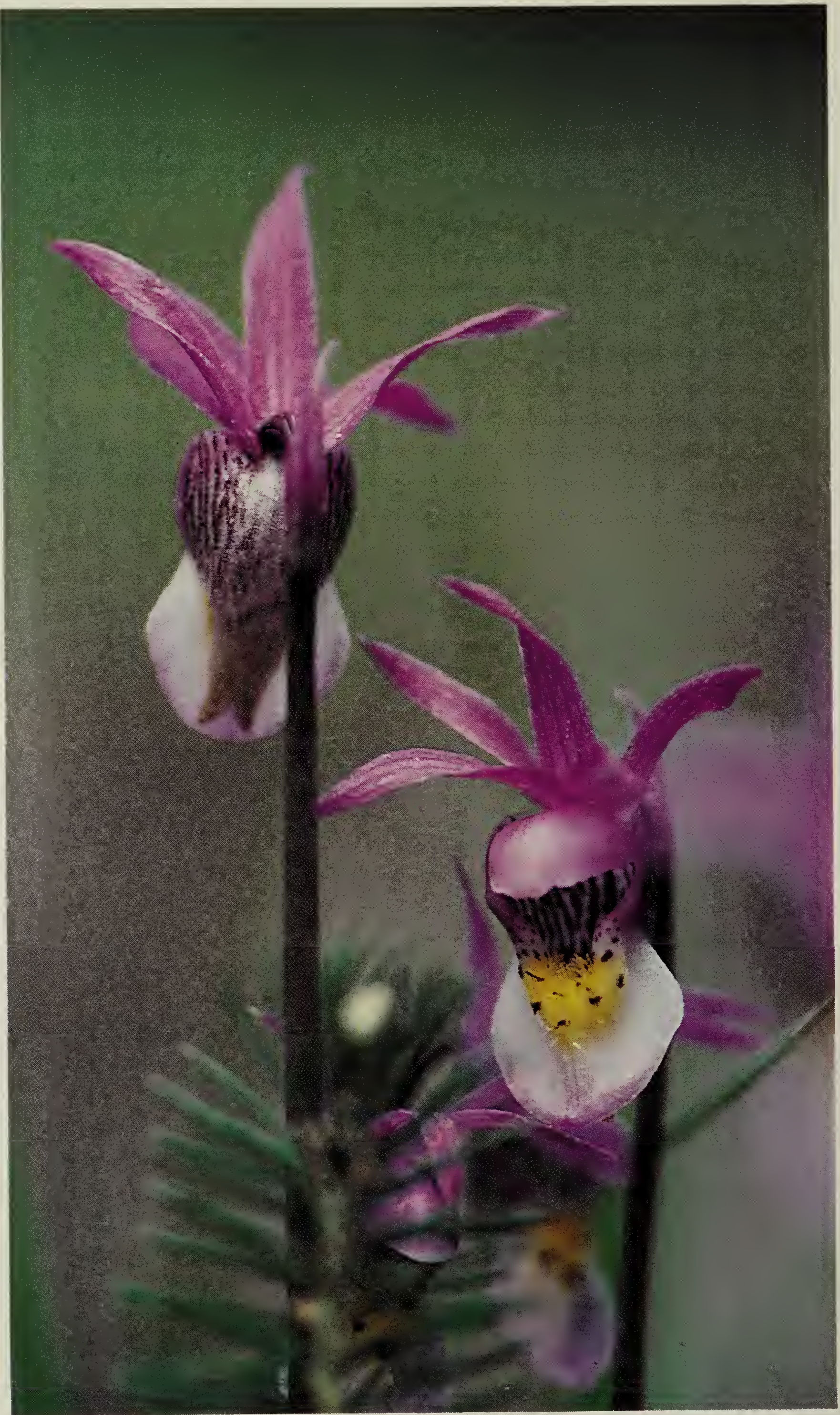




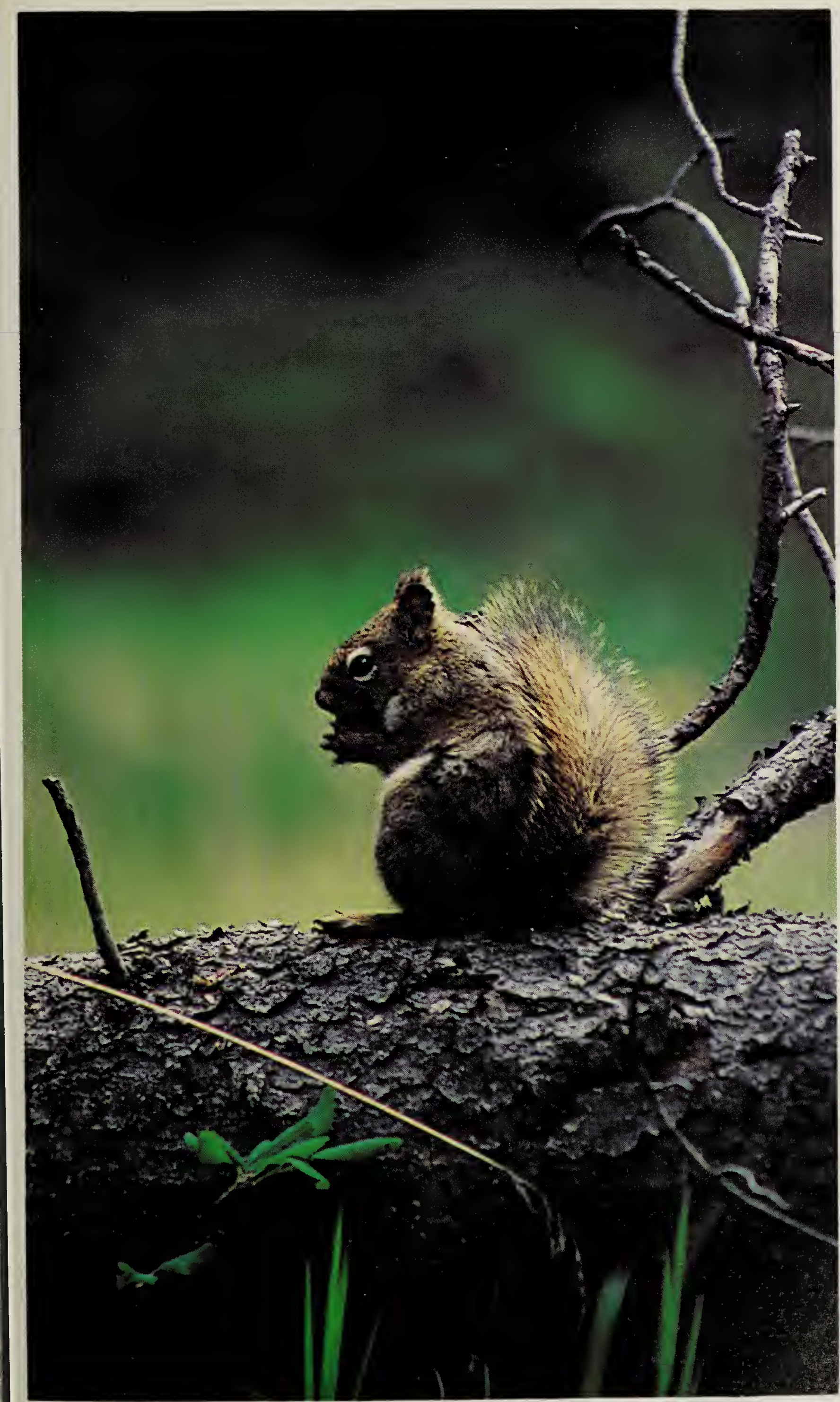




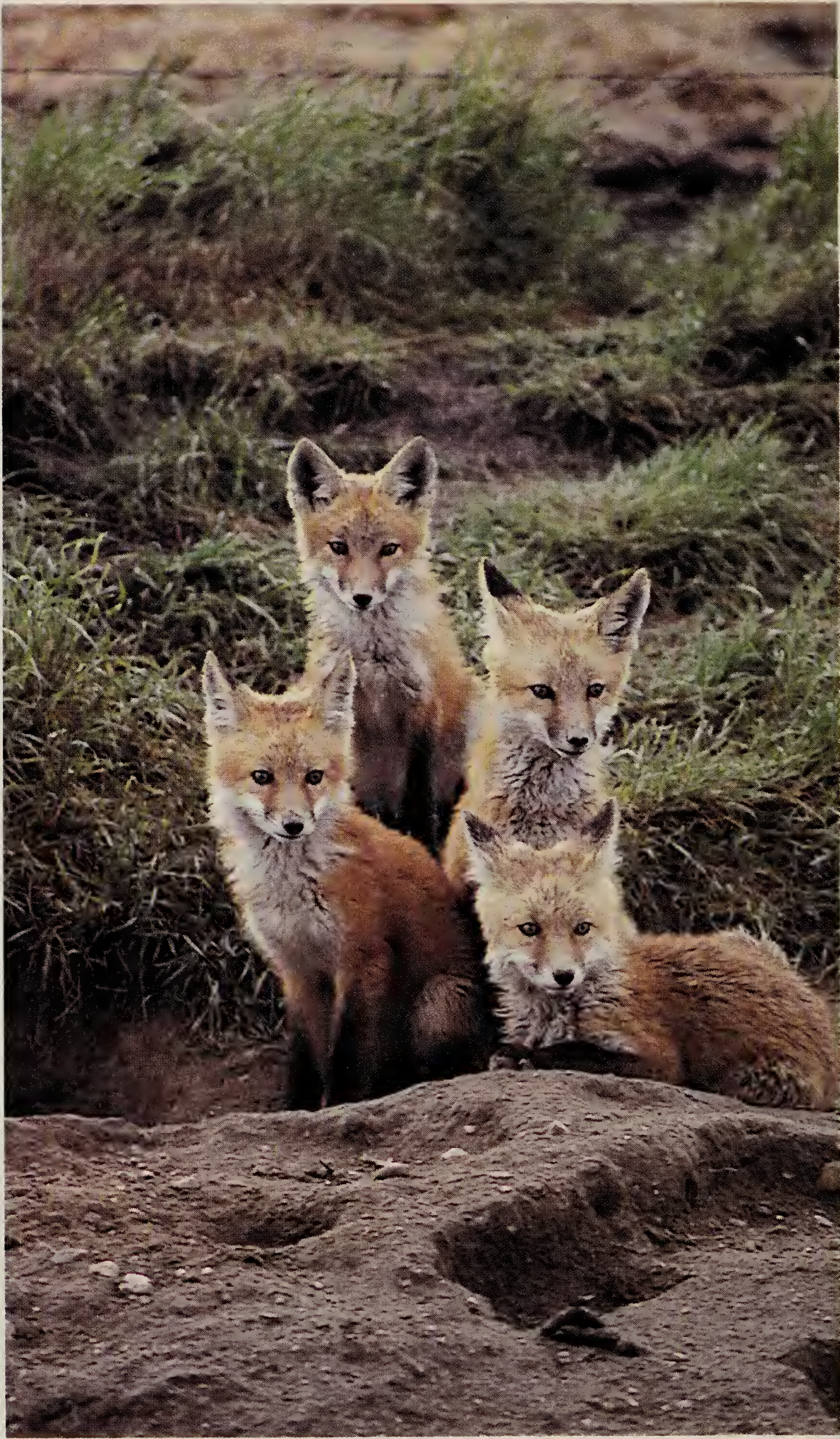


Dore Lake plots, and over 1,350 Fairy-slippers at Steamboat Mountain. Those estimates are certainly rough, but not wildly exaggerated. After counting orchids during a nearly birdless survey of a bog in Newfoundland, Bob Lamberton (in litt. to AJE) estimated 40,000 blooms of Dragon-mouth (Arethusa bulbosa) on that 40-ha plot.

I wasn't successful in naming all the flowers I found in 1972. A rather showy "pink chickweed" from the roadside on Porcupine Mountain remained unnamed, as Scoggan's keys to that group made no mention of colour, which of course was what had drawn my attention to that plant. His reliance for identification on tiny flower parts, only detectable by my eyes from fresh material (if then), was frustrating. The next two summers, in Saskatchewan ${ }^{3}$ and on the Alaska Highway, I used instead Flora of Alberta, ${ }^{5}$ which was much more user-friendly. In the 20 years since, far more and better illustrated wild flower guides have become available to naturalists, but being able to find your way through a plant key may save you trips to the herbarium for common flowers. More important still, you are more likely to save specimens if you hope to key them out, and some of your specimens may extend the known ranges of those species.
It helps if you can find simple keys to start with. Long ago, plant identification was taught in public schools. In 1956 I acquired a flora, ${ }^{7}$ authored by a high school inspector and two science masters in Ontario, but with coverage ranging across Canada. That book concentrated on the common plants; it had no pictures but its keys for identification were simple enough for any beginner to use, with a little patience. Grasses, sedges, and willows, except a few distinctive species, are better left to specialists, but it wasn't difficult to learn most of the obvious flowers in areas visited regularly. The main need is to want to do it.

1. ANONYMOUS. 1996. Muriel Carlson wins the 1996 Parks Canada award. Blue Jay 54:233-234.

2. ERSKINE, A.J. 1968. Birds observed in north-central Alberta, summer 1964. Blue Jay 26:24-31.

3. 1974. Off into the wet green yonder: birds and plants of a boreal bog. Blue Jay 32:33-37.

4. 1985. Some phenological observations across Canada's boreal regions. Can. Field-Nat. 99:188-195.

5. Moss, E.H. 1959. Flora of Alberta. Univ. Toronto Press.

6. SCOGGAN, H.J. 1957. Flora of Manitoba. Nat. Mus. Canada Bull. 140.

7. SPOTTON, H.B., A. COSENS and T.J. IVEY. 1937 (1st ed. 1910?). Wild plants of Canada. Toronto, W.J. Gage \& Co. Ltd.

\section{Bird Names}

Bonaparte, Charles Lucien Jules Laurent (1803-1857), Prince of Canino and Musignano, nephew of Napoleon, author and naturalist - Bonaparte's Gull.

Clarke, William (1770-1838), Captain in the U.S. Army, expedition leader and author - Clarke's Nutcracker.

Cooper, William (1798-1864) One of the founders of the New York Lyceum of Natural History - Cooper's Hawk. 